\title{
Translating Cultures and Crossing Borders: Catalan Poetry in Translation
}

\section{Traducción y poesía catalana: el acto de traducir culturas y cruzar fronteras}

DIANA CULLELL

UNIVERSITY OF LIVERPOOL

Artículo recibido el / Article received: 15-10-2015

Artículo aceptado el / Article accepted: 04-08-2016

ABSTRACT: Despite the current «great age of translation» (Bassnett, 2014), translating processes continue to pose countless challenges. Far from a simple linguistic transfer, translation demands a nuanced and intricate dialogue between not just languages but also cultures. Recent publications of Catalan poetry in Spanish and in English translations, and whose main aims are to present a translation that emphasises culture, identity and Catalan literary tradition, are perfect examples. Focusing on Xarnegos-Charnegos (Antologia) (2010), the bilingual publications of Joan Margarit, and the collections Forked Tongues (2012) and Six Catalan Poets (2013), the article will consider the different aims of each publication and their achievements. Finally, it will explore what this means for Catalan poetry at the crossroads.

Keywords: translation, Catalan poetry, bilingualism, crossroads, linguistic borders, identity.

RESUMEN: Pese a encontrarnos en «la gran era de la traducción» (Bassnett, 2014), los procesos de traducción continúan planteando grandes desafíos. Lejos de ser una simple transferencia lingüística, el ejercicio de traducir requiere un complejo e intricado diálogo no solo entre lenguas sino también entre culturas. Ejemplos de tal diálogo pueden encontrarse en publicaciones recientes de poesía catalana en traducciones al castellano y al inglés, cuyo principal objetivo es presentar una traducción con especial énfasis en la cultura, la identidad, y la tradición literaria catalana. Centrándose en la antología Xarnegos-Charnegos (Antología) (2010), las publicaciones bilingües de Joan Margarit, y las colecciones Forked Tongues (2012) y Six Catalan Poets (2013), el artículo considerará los varios fines y lo- 
gros de cada publicación. Finalmente, el trabajo explorará lo que esto significa para la poesía catalana y su futuro.

Palabras clave: traducción, poesía catalana, bilingüismo, fronteras lingüísticas, identidad.

\section{INTRODUCTION}

Susan Bassnett firmly stated that the twenty-first Century is «the great age of translation» (2014: 1). Indeed, Translation Studies, an academic area that has been gaining ground since the end of the 1970s, is currently enjoying solid critical attention as well as scholarly support and the due recognition as a research field. Nonetheless, both the translation process and the aims or objectives behind it remain a challenge at different levels: «[f]ar from being a straightforward process of linguistic transfer, translation involves complex negotiation between languages» (2-3). And it can be argued that the same negotiation mentioned by Bassnett extends to the cultures being translated from and to. A perfect example of such necessary mediation are some recent publications of Catalan poetry in Spanish and in English translations, whose main aims -or one of their main aims- are to present a translation that emphasises culture, identity and Catalan literary tradition ${ }^{1}$. Some Catalan poets, such as Joan Margarit, have published very successful self-translated bilingual publications (2007, 2009, 2012, 2015), which have been very favourably acclaimed in both Catalan and Spanish literary spaces. Other authors have even attempted to present, in a Catalan-Spanish bilingual format, a different understanding of Catalan identity, drawing on a hybridity heavily reliant on the translation of cultures as well as of languages, such as Xarnegos-Charnegos (Antología) (Trujillo, 2010). And, other poets have chosen to align themselves with much wider projects and participate in translations from Catalan into English that grant their work a readership outside their somewhat restricted linguistic borders, such as Forked Tongues (Palacios, 2012) or Six Catalan Poets (Ballart, 2013). The present article will consider the afore-

1. Catalan poetry -and therefore Catalan literary tradition- is understood in this article as poetry written in Catalan, regardless of the Catalan-speaking region it originates from. It has to be noted, nonetheless, that most of the case studies that will be analysed here are authors born or living in Catalonia. 
mentioned poetry publications into Spanish and into English and look at Catalan poetry and identity in translation, focusing on how in recent times it has managed -successfully or not- to translate a culture, or cultures, besides a language and to cross borders towards Spain and even beyond the Iberian Peninsula.

\section{XARNEGOS-CHARNEGOS (ANTOLOGÍA): EMPHASISING HYBRIDITY}

Xarnegos-Charnegos (Antología), edited by Noemí Trujillo, is a collection of poems by 18 authors published in 2010. The title of the anthology highlights its Catalan and Spanish bilingual format in terms of both language and cultural references, and it also hints at what the topic of the poems will be: that of xarneguisme. In its current form, the term xarnego refers to an immigrant from a Spanish-speaking region living in Catalonia or to the children of immigrants in Catalonia that have failed to fully become part of Catalan society, ${ }^{2}$ and it is linked to the waves of Spanish immigration that arrived to Catalonia under Francisco Franco's dictatorship from the 1950s to 1975 (Candel, 1964: 86; Cullell, 2011) . $^{3}$ It is also a derogative label that has marginalized groups in Catalan society due to their Spanish roots and their use of the Spanish language, which seems to be the one that many of them favour in their literary work. Therefore, the choice of title was not an innocent one, and it most certainly aimed at catching the public's attention: the editor states that the aim of the anthology is to cast a new and positive light onto the term xarnego -emphasizing the cultural and hybrid richness it affords- and to defend bilingualism as well as pluricultural roots. And the work of the selected poets, some of whom were born in Catalonia and others in different regions of Spain, is indeed presented in a completely bilingual manner, with each and every part of the book both in Spanish and in Catalan. This is certainly a striking characteristic in a potentially controversial publication: literature that deals with xarnego topics usually presents a hybrid sense of identity, where the borders between what is Spanish and what is Catalan are constantly crossed and

2. For more information, see the full definitions of the term xarnego/Charnego in the Diccionario de la Real Academia de la Lengua Española and in the Diccionario de María Moliner, summarised above.

3. Els altres catalans (1964) by Francisco Candel is without a doubt the most complete work on xarnegos and xarneguisme to date, and it provides key definitions of the term as well as an indication of the marginalisation and tension xarnegos face, or have faced, in Catalonia. For other analysis of xarneguisme and their cultural production, see Farràs \& Cullell (2009), Resina (1999a, 1999b) and Vilarós (2003). 
boundaries become blurred, and where most tensions revolve around the use of the Spanish language. Spanish-language works by Catalan authors are not an uncommon feature, but since the cultural movement la Renaixença $a^{4}$ established Catalan language as the symbol of the Catalan nation's identity in the 19th Century, and again since Francoism, literary activity in Spanish has been frowned upon in Catalonia (King, 2002, 2005; Cullell, 2011: 87). Xarnegos-Charnegos (Antología), however, manages to bypass this by providing bilingual versions of the whole piece -including bilingual introductions, presentations, preambles and epilogues- and by concealing which was the original language and never disclosing what part is the actual translation.

Besides the obvious bilingual manifestation of the anthology in its form, numerous poems in the publication deal with issues surrounding language: the struggle that writing in Spanish in Catalonia presupposes and which one would expect to feature prominently is, however, conspicuously absent from this poetry. Most compositions in Xarnegos-Charnegos (Antología) choose to emphasize the richness that the two languages can afford, focusing on and applauding the ease with which people navigate the two linguistic systems in Catalonia and the translation processes that make it possible. Poems such as «L'abraçada de la traducció» // «El abrazo de la traducción», by Antonio García Lorente, link the process of translation and the use of two languages to a civic behavior -with a special emphasis on the idea of tolerance- that defines Catalan people, a cultural gift that should be embraced and celebrated:

\author{
Afirmo i ratifico la vida en tolerància, \\ per això m'he lliurat a la traducció, \\ igual que d'altres que em van precedir. \\ Aquesta és nostra forma catalana \\ d'honrar el nostres germans. \\ Aquesta tinta de l'amor \\ la concedeix la Mare Terra, \\ tu la revifes \\ amb generosa lucidesa.
}

(García Lorente, in Trujillo, 2010: 34)

4. Some scholars have been openly critical about the role that the Renaixença had in establishing an idea of Catalan identity. Stewart King, for example, stated that «los renaixentistas edificaron una homogeneidad imaginada» (2006: 8), creating a string of myths that defined what was Catalonia and who the Catalan people were. Furthermore, he continued, «a través del conjunto de sus escritos se formó una narrativa - una historia- sobre la identidad de la nación catalana que fue aceptada como válida para toda la comunidad» (9). 


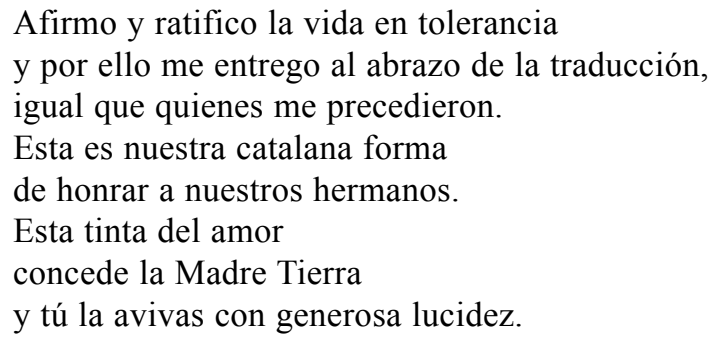

(García Lorente, in Trujillo, 2010: 35)

The poem traces an understanding about languages and a civic manner back to its ancestors, almost establishing a tradition in the act of translating. Spanish speakers are seen in the poem as brothers, although the poetic voice remains ambiguous as to whether the Mother Land refers to Catalonia or Spain. Many of the compositions in the anthology make precise references to the two languages that coexist around the poetic voices, but they seem to imply that regardless of the linguistic system being used, they lead to just one culture:

Barcelona m'ancora a tu;

en els seus carrers, places i bars

reprenc el pols

a les teves paraules i presència.

Perquè sabem

d'una bella geografia

que ens toca l'ànima

amb les seves llengües i cultura,

la seva gent i el seu mar.

(Aragón Rodríguez, in Trujillo, 2010: 134)

Barcelona me ancla a ti;

en sus calles, sus plazuelas

y sus bares retomo el pulso

a tus palabras y tu presencia

a sabiendas

de una hermosa geografía

que nos toca el alma

con sus lenguas y su cultura,

sus gentes y su mar.

(Aragón Rodríguez, in Trujillo, 2010: 135) 
The lines in the poem by Alicia Aragón García seem to offer an echo of what the anthology wants to convey: the two versions of the compositions, side by side, result in the portrayal of one hybrid culture -in singular form- able to tie and bring together elements of both sides so that the outcome is one single and inspiring entity, regardless of how complex the idea of xarneguisme really is. The use of two languages by the poetic voices does not threaten their identity or their inclusion in a certain community, it rather enriches it. At the same time, the poets are presenting Catalan and Spanish languages as equals, and the transition from one language into the other is conveyed as a fluid shift devoid of hindrances, highlighting the imaginary borders that have been erected between the languages throughout history: «Passo/ per un llindar fictici» // «Cruzo ficticias lindes» («Oda a la nopàtria» // «Oda a la nopatria» by Antonio García Lorente, in Trujillo, 2010: 28-29).

The scholar Montserrat Guibernau sustains that intellectuals have, throughout history, made use of rational and emotional arguments to develop nationalist identities and movements (2004: 28-32). Those centered on a collective sense of identity are the emotional arguments, which «emphasize the sentiment of belonging to a cultural and territorial community which has suffered and rejoiced together throughout time», and they comprise language, culture, history, territory and art (30). The role such emotional arguments play in society should not be underestimated, as «individuals who enter a culture emotionally charge certain symbols, values, beliefs and customs by internalizing them and conceiving them as part of themselves. This emotional charge is crucial because it builds up their identity and facilitates the spread of the nationalist sentiment» (Guibernau, 2004: 152). As seen above, Xarnegos-Charnegos (Antología) clearly employs language as an emotional argument, one that becomes quickly entangled with the rest of the arguments. The aforementioned «Oda a la nopàtria» // «Oda a la nopatria» by Antonio García Lorente makes obvious reference to the literary piece «Oda a la pàtria» (1833), by the Renaixença poet Bonaventura Carles Aribau. The poem, which praised Catalan language as well as Catalonia, is considered the piece that marked the beginning of the Renaixença movement, but García Lorente's composition might also refer to the fact that Aribau had mostly written in Spanish before publishing the acclaimed «Oda a la pàtria». The poem in Xarnegos-Charnegos (Antología), in any case, makes clear references to Catalan literary and artisitc tradition and underlines key landmarks in its hisotry, as does the also cited «L'abraçada de la traducció» // «El abrazo de la traducción» (34-35), with crucial figures such as Ramon Llull, Ausiàs March and Joan Boscà, mentioned in the composition. García Lorente credits these authors with the literary modernisation of the 
Iberian Peninsula, and proceeds to also highlight foreign authors -such as George Orwell- who paid homage to Catalonia and its people in their writing, using their example to illustrate the value of Catalan identity and culture within and outside the limits of Spain.

Many of the poems in the anthology are also heavily inscribed with culture, thus adeering to another of the emotional arguments quoted by Guibernau. The preferred form of culture in many cases is the folkloric one, and a perfect example of this is the composition «Jo, xarnega de mena» // «Yo, charnega por naturaleza» by Carolina Ibac, which replicates at the beginning of the poem the two verses from the popular Catalan folktale «En Patufet» (in Trujillo, 2010: 176-181). This poem also contains plenty of references to easily recognisable Catalan objects, such as the «barretina», the Catalan hat, or the «cuatro barras», the Catalan flag. Other poems, such as «Sardana» (García Lorente, in Trujillo, 2010: 26-27), include mentions of the centuries old circular dance from the Catalan regions, a part of popular culture imbued with the capacity to host and foster a sense of identity: «A un forn de melodies/ hi cap l'ésser dels pobles» // «Un horno de melodías/ aviva el ser de los pueblos» (26-27). Whether it is popular culture or a more highbrow manifestation, the elements that have been mentioned so far are successfully turned into symbols in the mind of Catalans and xarnegos, and as Guibernau stated, «symbols are effective because they are imprecise and conceal the heterogeneity of the nation. Symbols transform difference into the appearance of similarity, thus allowing people to invest the 'community' with ideological integrity» (Guibernau, 2004: 32). Through these symbols in the poems in Catalan and Spanish in the anthology are able to effectively bind together readers -and poets- from different cultural and social backgrounds.

Inextricably linked to aspects of language and culture within XarnegosCharnegos (Antologia) is history, particularly Catalan history and xarnego history, as one can never forget that «[1]a historia [...] es una herramienta poderosa para crear un sentido de cohesión social y cultural» (King, 2006: 131). Key historical events such as the Guerra dels Segadors or the Diada understandably assist in shaping an identity for Catalan people and are seen as foundational moments for Catalonia (Trujillo, 2010: 34-35, 176-177), but other historical episodes that are much more personal and subjective are also presented as crucial, in particular the precise moment in which the poetic voice or their ancestors came into contact with Catalan culture for the first time. The poems that deal with this topic might illustrate one's journey (or the ancestors' journey) to Catalonia, framing the experience as a decisive moment for the formation of their identity. A striking feature of these poems, such as «Baldomero» (Miranda, in Trujillo, 
2010: 50-53) is a sentiment of debt and, very important, also admiration towards the ancestors: «ja fa uns quants anys que va arribar a Catalunya,/ a viure, a treballar,/ a casar-se, a treballar,/ a aixoplugar-se, a treballar,/ a ser pare, a treballar,/ a treballar, a treballar» // «vino años ha a Catalunya,/ a vivir, a trabajar,/ a casarse, a trabajar,/ a cobijarse, a trabajar,/ a ser padre, a trabajar,/ a trabajar, a trabajar» (50-51). The esteem these poems also display acknowledge the role the xarnegos silently carried out when they arrived in Catalonia: they contributed to build Catalonia as we know it today, shaping its future and therefore accelerating their right to become part of Catalan society.

Just as the xarnegos become part of the history of Catalonia, their histories and stories become interwoven with territory. Territory becomes in XarnegosCharnegos (Antología) a very powerful emotional argument that seems to unite many of the other clusters and emphasise a sense of identity. The Catalan landscape appears sometimes opposed to the xarnego's former homeland, as is the case of «Arrels»// «Raíces» (Otero, in Trujillo, 2010: 154-159). In «Arrels» // «Raíces» Ana Otero juxtaposes Extremadura, where the poetic voice originates from, to Barcelona, the city that welcomed her and where her children were born: «I tu vas donar-me el teu amor, Barcelona,/ Catalunya, terra de la Mediterrània,/ vaig fer-me dona al teu costat,/ tu eres la mare que havia deixat enrere» // «... tú, Barcelona, me diste tu amor./ Cataluña, tierra del mediterráneo,/ me hice mujer creciendo a tu lado,/ siendo esa madre que atrás había dejado» (154-155). The city is personified in this poem and in many other compositions, becoming another character that accompanies the poetic voices in their personal journey and nuances their definition of identity. The streets of Barcelona and its neighborhoods are also recurrent images in the anthology, demonstrating the connection the poetic voices feel towards the territory they inhabit, such as in «In Itinere» (Aragón Rodríguez, in Trujillo, 2010: 134-135). The voices blend with the territory and acknowledge a symbiotic connection between the two, one that allows them to reciprocally redefine or specify their identity.

Xarnegos-Charnegos (Antología), in its bilingual format and undisclosed translations into or from Spanish and Catalan, exposes a permeable cultural distinctiveness that allows a hybrid sense of identity to flourish. Equally, it offers brave resistance to inflexible modes of identity, as identities traditionally «act as mechanisms of social inclusion and exclusion, creating imaginary limits between those who belong and those who do not belong to specific communities» (Guibernau, 2004: 3). The bilingual anthology expands modes of interpretation, and presents an idea of identity whose pedagogical manner or even pedagogical agenda should not be overlooked. 


\section{JOAN MARGARIT: BILINGUAL PUBLICATIONS AND CULTURES IN TRANSLATION}

Joan Margarit, born in Sanaüja (Lleida) in 1938, has been at the forefront of Catalan poetry for almost three decades, and he is one of the best wellknown contemporary Catalan poets inside and outside the Iberian Peninsula. A poet who regularly publishes his work in bilingual editions translated -or re-written- by himself, Margarit has enjoyed immense success in both the Catalan and the Spanish literary spaces, managing to thrive in the crossing of linguistic and cultural borders that divide the two literary fields. Joan Margarit's first publications in the 1960s saw the light in Spanish, although he abandoned his initial choice of language in 1980 and moved to bilingual editions in the late 1990s, when the closure of the poetry series within Columna Edicions (where he used to publish) forced Margarit to find a new editor and publishing house. This turned out to be the Madrid-based publishing house Hiperión, which he approached with a proposal for a bilingual publication that would not be a self-translation of his poetry in Catalan into Spanish but actually a work written simultaneously in two languages (Margarit, 2011: 251). ${ }^{5}$ The use of both Spanish and Catalan has never been a rare event for Catalan authors, and the linguistic circumstances of writers born in a Catalan-speaking family during or after the Spanish Civil War make such reality a common occurrence. Margarit felt compelled to justify the change to regular bilingual editions in the prologue of the first book published by Hiperión, Estació de França (1999), which bore the title «Sobre las lenguas de este libro». In this prologue, the poet listed the lack of cultural referents in Catalan as a reason for his initial adherence to Spanish, ${ }^{6}$ although the most interesting aspect of the prologue was without a doubt Margarit's understanding of his bilingual work, which he envisioned as a collection of poems not written in Catalan and subsequently translated into Spanish but rather as a collection of compositions

5. See Cullell (2014) for a detailed account of Joan Margarit's transition from writing poetry in Spanish to writing in Catalan, to finally publishing bilingual editions.

6. Margarit has discussed his education in Spanish under Franco in multiple occasions and contexts, and he has placed great emphasis on the negative consequences that it had with regards to cultural references and people's confidence in their mother tongue when attempting a literary career. Some of his ideas can be read in the Epilogue to Se pierde la señal (2012), where he stated: «yo no pude escuchar nunca el catalán en la escuela. Esta represión llevada a cabo mediante la amputación del habla es de las más duraderas y crueles. Ahora sé que moriré con ese miedo y esa fragilidad en torno a la percepción de mi lengua, que quiere decir, también, de mi vida.» (Margarit, 2012: 162). 
written simultaneously in both languages (Margarit, 1999: 9). For Margarit, the Catalan and Spanish forms of the poem remain independent throughout the writing process, although they share the same source or foundation: «todas las versiones, modificaciones y vueltas a empezar que sufre en mis manos un poema las he realizado en catalán y en castellano a la vez.» (9). This practice is akin to Grutman's idea of a «simultaneous» self-translation, where a writer constantly switches between both versions of their text and where translation is also part of the creative process. This procedure is directly opposed to what Grutman conceives as «consecutive» translations, which are texts translated by their author into another language once the original version is completely finished (2009: 259). The process Joan Margarit alleges to be following bears much in common with the unwillingness felt by many self-transaltors to refer to a «transaltion» when discussing the textual relation between the two versions of their work (Gentes, 2013: 266-267).

Just as in Xarnegos-Charnegos (Antologia), the emotional arguments listed by Guibernau (2004: 28-32) as crucial clusters used by intellectuals to develop nationalist identities and movements are widely employed in Joan Margarit's poetry. Language, culture, history, territory and art become part of the verses and the poetic structure in Margarit's work. Language, culture and art seem to work at a par in the poetry of the Catalan author. It has already been discussed how Margarit has managed to cross the vastly problematic linguistic and cultural borders that divide the Catalan and the Spanish literary fields, and the way in which he conceives his creative process in both languages. His relationship to language, however, is not as conflict-free as one would expect in a self-translated bilingual author. Margarit has approached in many of his poems the complex relation existing between Catalan and Spanish, putting Catalan language -and therefore Catalan culture- at the forefront of his discourse:

El castellà m'ofega i no l'odio.

No en té la culpa de la seva força: de la meva feblesa, encara menys. L'ahir era una llengua ben travada per pensar, per pactar i per somiar, que ningú ja no parla: un subconscient de pèrdua $\mathrm{i}$ cobdícia on ressonen bellíssimes cançons.

El present és la llengua dels carrers, maltractada i espúria, arrapada com l'heura a les ruïnes de la historia. És la llengua en la qual escric. 
També és una llengua ben travada per pensar, per pactar i per somiar. I les velles cançons se salvaran.

(Margarit, 2012: 38)

Me ahoga el castellano y no lo odio. No tiene culpa alguna de su fuerza y menos todavía de mi debilidad. El ayer fue una lengua bien trabada para pensar, pactar, soñar, que ya no habla nadie: un subconsciente de pérdida y codicia donde suenan bellísimas canciones. El presente es la lengua de las calles, maltratada y espuria, agarrándose como hiedra a las ruinas de la historia. La lengua en la que escribo. También es una lengua bien trabada para pensar, pactar. Para soñar. Y las viejas canciones se salvarán.

(Margarit, 2012: 39)

The references to his native Catalan language, and how it defines one's identity (see, as an example, «D’on ser, on anar» // «De dónde ser, a dónde ir» in Margarit, 2012: 138-139) are paired with mentions and citations of key figures in Catalan literary history. From odes and homages to other poets writing in Catalan, such as «Joan Maragall» (2012: 90-91) or «Comentari de text» // «Comentario de texto», about Vicent Andrés Estellés, Joan Margarit acknowledges the strong Catalan culture with which he identifies (2009: 82-83). Margarit tried, in fact, to explain to Spanish readers in one of his prologues the complexity surrounding bilingualism and pluriculturalism in Catalonia and how this conditioned his poems (Margarit, 2011: 251). To do so, the poet turned to the Catalan term frontissa, which can be translated as hinge. In his explanation, frontissa becomes a highly charged word, with abundant implications when it is applied to a literature at the crossroads. With the expression «frontissa», Margarit positioned his work at the aforementioned crossroads between two cultures, as a sort of connecting element between the two (Cullell, 2014: 102-103). 
The blending of history and territory in the poetry of Joan Margarit can easily be identified as one of the most manifest emotional arguments in his work, mainly through the Catalan geography that appears once and again in his verses, and that is mostly construed around the city of Barcelona. Such prominence is given to the Catalan capital that the poet published, in 2007, an anthology in Catalan, Spanish and English whose focus was Barcelona, its neighborhoods and particular points in its topography that held emotional connections for the author: Barcelona amor final. In the poetry of Joan Margarit, as in many other poets throughout Catalan literary history, Barcelona features as much more than just another character; it develops into a being that is able to create solid bonds with the poetic voice and act as a sympathetic companion. A constant in Margarit's Barcelona is Montjuïc Cemetery, which besides the crucial role this area has played throughout the city's history -from the 3rd Century $\mathrm{BC}$ to recent times-, the graveyard becomes part of the emotional fabric of the author and the poetic voice as it holds the graves of two of Margarit's daughters. The cemetery features as one of the sub-parts or chapters within Barcelona amor final (Margarit, 2007: 151-162), and in it the reader is immersed in what appears to be a private dialogue between Montjuïc, the poetic voice and their ghosts - both historical and personal. The history of the city becomes entwined with the poetic voice's personal history, blurring its frontiers and charging this particular geography with great emotional meaning:

Alguna cosa en queda, de les ànimes, com la brisa que s'alça després de passar algú i que fa voleiar amb delicadesa la randa a una finestra.

Pel camí d'aspres pedres que no obliden però callen, severes, el que saben, el vent ens du el silenci de les llàgrimes per vides com la nostra, ja perdudes. «Concessió perpètua», la terra sempre dura, fileres de xiprers: provincià teatre de la mort.

El nostre amor és com el que ells perderen.

$\mathrm{S}$ 'ha fet de nit. Mira, des del més alt d'aquest turó dels morts, sota el cel negre, els llums de la ciutat: un vaixell ancorat al firmament que ens espera a nosaltres per salpar.

(Margarit, 2007: 158) 


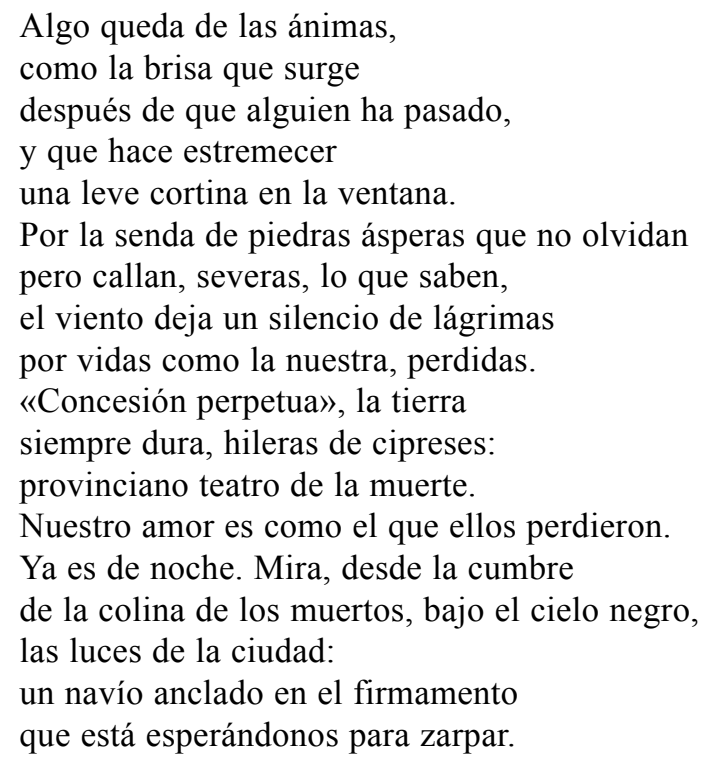

(Margarit, 2007: 406-408)

The souls that one can almost feel and read could be those of the people that have forged Barcelona and Catalonia into the city it is today, but they can also be the two daughters whose graves the poetic voice diligently visits. The «ellos» once again points towards a plural history and Catalan identity, and blends with the more private and personal «Nuestro». Here, the landscape and the history of Montjuic blend with the emotional landscape and personal history of the poetic voice, once again drawing attention to the fact that landscapes «are emotionally charged» (Guibernau, 2004: 31 ) and can successfully embody a Catalan identity. It is important to stress that, throughout his poetry in selftranslation, Joan Margarit effectively provides a contact zone for the Catalan and the Spanish literary systems, a negotiation within literary fields built on a translation of culture.

\section{FORKED TONGUES AND SIX CATALAN POETS: TARGETING WIDER AUDIENCES}

Besides the publications mentioned so far, in the last few years there have been examples of poets -and editors- that have aligned themselves with wider projects, namely with translations into English, that grant their work a larger readership outside the Spanish borders. There have also been some very 
interesting publications that include all the official languages of the Spanish Peninsula -such as El poder del cuerpo: antología de poesía femenina contemporánea, edited by Meri Torras (2009) and Manuel Rivas' La desaparición de la nieve (2009). These publications, however, were intended -or at least destined- to remain within the Spanish geographical or at the very least linguistic borders, as they had Spanish as the lingua franca. In contrast, there have been some publications that have deliberately targeted an audience outside the Spanish state, and in order to do that they have translated their poetry into English. Of course, translations of Catalan poetry into English are not anything new, and there have always been Catalan authors translated for the Anglophone world, even collections of Catalan poetry in English (for example, David H. Rosenthal's Modern Catalan Poetry: an Anthology, 1979, or Iolanda Pelegrí and Anna Crowe's Light off Water: XXV Catalan poems, 1978-2002, 2007). It is nowadays, nonetheless, when we find relatively young authors and editors who want to reach far beyond translations into Spanish, actively conveying a desire to cross borders and present Catalan poetry to Europe and the world, not just to Spain. Forked Tongues, published by Shearsman Books in 2012, which is a collection that also includes poets writing in Galician and Basque, is one example of it. Compositions by Vinyet Panyella, Susanna Rafart, Gemma Gorga and Mireia Calafell were rewritten in the anthology by Irish poets. Thus this publication also attempted, very significantly, to build bridges with other groups in Europe that exist within similar social and historical contexts. To this end, Manuela Palacios, the editor, states in the introduction with regards to the trope of the forked tongue:

It is primarily intended to suggest the relationship between the source and the target language... But the notion of the forked tongue arises also of the bilingual condition both of the writers and of the communities involved in this anthology. Galicia, the Basque Country and Catalonia each have two official languages, and so has Ireland. Their writers' mutual understanding in this respect, alongside these communities' sundry political and cultural bonds, lie as the main motivations for the present selection of writers (Palacios, 2012: 7).

Palacios goes even further, stating that «[t]ranslation is a performative act by which the Other is acknowledged», and that the act of translation is «a new opportunity to renegotiate our cultural bonds on fairer terms» (Palacios, 2012: 7). The chance that translation into English offers of negotiating new understandings of identity -one's identity as well as how it is perceived by others-, is what seems to be motivating these authors. The collection Six Catalan Poets 
(2013), which includes poems by Josép Lluís Aguiló, Elies Barberà, Manuel Forcano, Gemma Gorga, Jordi Julià and Carles Torner, ${ }^{7}$ all of them translated by Anna Crowe, ${ }^{8}$ is another example. It was published by Arts Publications, as part of a series that brings contemporary poetry from around Europe to English-language readers (Ballart, 2013: 9), and that has also published Six Basque Poets. In the Series Editor's Preface, Alexandra Büchler states that «any translation is the outcome of a dialogue between two cultures» (2013: 9), and one cannot ignore that that is precisely what these poets are aiming for. The editor of the Catalan collection, Pere Ballart, mentions that Catalan literature -and poetry in particular- has had to wait for occasions in which to «reveal its quantity and excellence to the outside world» (2013: 11). Ballart also laments the fact that in many occasions Catalan literature stills remains within the Catalan borders and struggles to get any substantial visibility abroad (11), stating that the anthology would like, most of all, «to succeed in bringing it to the maximum number of readers» (22). Ballart then reminds readers of Gabriel Ferrater's grim claims back in 1953, in his essay «Madame se meurt», published in Insula, where the celebrated Catalan author revealed he feared that Catalonia would end up using another language as an instrument of expression, and that Catalan literature would soon become extinct (Ferrater, 1953: 12). In response to Ferrater's harsh verdict, what these two anthologies crave to do -and what these poets and their work translating cultures and crossing borders attempt to prove-, is to present Catalan poetry and identity in translation, to demonstrate that, as Ballart says, "'Madame' is alive and well, and poetry in our language aspires to being taken for granted as a normal phenomenon, just as it is in any other country» (2013: 15).

The poets whose work is collected in Six Catalan Poets and in Forked Tongues want to cross borders outside the Iberian Peninsula and have a very clear goal in mind: the portrayal of Catalan literature (and poetry specifically) as a literature that is alive, vibrant and fruitful. But most of all, they aim to present it as an ordinary and common phenomenon, based on the awareness that they have something of absolute value to convey to foreign audiences: it is just another literature within Europe and the world. Maybe it is precisely due to these aims and objectives that their poetry is not invested with the Catalan

7. It is important to note that Catalan poetry is understood in Six Catalan Poets as poetry written in the Catalan language, and it includes authors from Catalonia, the autonomous community of Valencia and the Balearic Islands.

8. Significantly, Anna Crowe is also Joan Margarit's translator into English, and she has vast experience translating from both Catalan and Spanish. 
traits that we find so predominant in Xarnegos-Charnegos (Antologia), or even in Joan Margarit's bilingual poetry. In contrast to many of the compositions seen in the previous case studies, the authors included in Six Catalan Poets and in Forked Tongues seem to favour -for example- artists, authors and literary traditions outside of their own, referring to global canons rather than a Catalan one. Such is the case of «En una breu estada» // «In this brief stay» by Susanna Rafart, where the poem seems to take inspiration from a poem by Emily Dickinson:

Soul, take thy risk

Emily Dickinson

Arrisca't, ànima dorment,

hi ha gebre al fang de l'esperança,

cau la llum dictada sobre el món.

Al mur obert del teu silenci,

Cants muts en heures esberlades

I el mar creixent a boca de fiblada.

Res no obtindràs en la imbatuda calma.

(Rafart in Palacios, 2012: 142).

Soul, take thy risk

with Death to be

were better than be not

with thee

- Emily Dickinson

Take a chance, sleeping soul:

in the predictable light that falls on the world

frost glints like hope on the mud.

On the open wall of your silence

dumb chants writ between the ivy tendrils, the sea encroaching with its mouth of hurts.

There is nothing to be had in the face of such calm.

(Rafart in Palacios, 2012: 143). 
Similarly, «Llegint Matsu Bashô» // «Reading Matsuo Bashō» by Gemma Gorga (in Palacios, 2012: 152-153), establishes links with $17^{\text {th }}$ Century Japanese poetry and the haiku tradition. Referencing one of the most important haiku writers, Gorga crosses borders and presents a poetry that learns from, and is wide open to, foreign traditions. The same applies to art, where the poets extend their verses to include in them artists from different traditions, as can be seen in «Autoretrat en nu» // «Nude Self-portrait», by Vinyet Panyella: «Tu no hi ets./ No esguardaràs el nu fendit per la rialla magenta de la carn./ Jo no sóc ella./ La distància que ens separa és la mirada/ que va de Pierre Bonnard a Lucien Freud» // «Your are not there./ You will not regard the nude cut in two/ by the magenta guffaw of the flesh./ I am not she./ The distance between us is that of the gaze/ from Pierre Bonnard to Lucia Freud» (Panyella, in Palacios, 2012: 126-127). Opposed to the Catalan history that permeated the first case studies analysed, in these two anthologies the poets make use of an inclusive historical account that far surpasses that of the Iberian Peninsula. The authors collected in these two anthologies go back to ancient times to make sense of the world around them, such as in the poem «Gest d'Abraham» // «Abraham's gesture», by Carles Torner (in Ballart, 2013: 38, 41), where the poetic voice attempts to come to terms with the homicide of children around the world -in places such as Europe, Latin America, Bosnia or Chechnya- through the biblical figure:

Fa uns quatre mil anys, algú va decidir no matar més infants.

Potser va ser la mà de l'àngel, de l'intrús, qui va aturar la mà aixecada amb el punyal tot just abans del crim. Potser va ser la veu interior.

Potser.

Va ser en tot cas un gest:

deixar de matar infants.

[...]

Abans, però, potser, amb el puny alçat, mentre la veu de l'àngel l'eixordava, Abraham, tancant els ulls, veié tot el futur alçat

[...]

nens deportats, exterminats

a la diàspora europea,

màrtirs de cap a cap d'Amèrica Llatina, 
guerres de religió a Jerusalem, neteges ètniques a Bòsnia, crims a Txetxènia

(in Ballart, 2013: 38, 40).

About four thousand years ago someone decided not to kill any more children.

Maybe it was the angel's hand, the intruder, that stopped the raised hand with the knife just before the crime. Maybe it was the voice inside him.

$$
\text { Maybe. }
$$

In any case it was a gesture:

to leave off killing children.

[...]

And yet before that, maybe, with the knife poised, while the angel's voice deafened him, Abraham, closing his eyes, saw the future raised up,

[...]

children deported, exterminated

in the European diaspora, martyrs the whole length of Latin America, religious wars in Jerusalem, ethnic cleansing in Bosnia, crimes in Chechnya

(in Ballart, 2013: 39, 41).

The poetic voices featuring in the collected books also travel widely, as can be seen in «El cel sobre Berlín» // «The sky above Berlin» (Gorga, in Ballart, 2013: 70-71), or «Al museu arqueològic de Damasc»// «At the archaeological museum in Damascus» (Forcano, in Ballart, 2013: 88-89), but most importantly they encourage the reader to travel far away, and to explore what lies in remote and distant shores:

Les roses d'Isfahan, o de l'Eufrat els lliris salvatges que creixien a les ribes. Els jardins d'olor a Mossul, i a Damasc l'esclat dels gessamins. Les flors de mirra del Sudan, i a Khartum els dos grans afluents del Nil arribant-se l'un a l'altre 
com set i aigua, vaixell i port, desig i cos.

No et conformis amb els geranis d'un test a la finestra.

(Forcano in Ballart, 2013: 92)

The roses of Isfahan, or the wild iris that grow on the banks of the Euphrates.

The scented gardens at Mossul, and in Damascus the dazzle of jasmine. The myrrh blossom of Sudan, and at Khartoum the two huge tributaries of the Nile rubbing shores one with the other like thirst and water, vessel and port, desire and flesh.

Don't be content with the pot of geraniums in the window.

(Forcano in Ballart, 2013: 93)

These poets seem to place special emphasis on specific voyages, and the poetic voices travel just as they want their poetry to do, crossing borders and experiencing what lies beyond them. The crossing of boundaries necessarily implies the intersection of languages, and it is striking to see that these poets seem more concerned about the blurred boundaries and empathies between linguistic systems -what becomes lost or fades in translation-, than in paying homage to their own language. It could also be argued, of course, that in an indirect manner they are doing precisely that: they are writing in Catalan and considering Catalan one of the languages to be translated. Such is the case of «Destraduir Europa»// «Untranslating Europe»: «vas esmussant les cases/ a cops de traduir uns versos traduïts/mentre l'origen se t'allunya/ i em dius que tant se val, catalans, tan se val:/ traduïm a la llengua d'un país sense forma/ on ens esborren cada dia els vells contorns/ encongits foradats estrafets sense fre/ com podem traduir-los diluir-los sobreviure?» // «you are busy blunting the sharp edges of houses/ by translating lines of translated poetry/ while the source recedes even farther/ and you tell me it doesn't matter, catalans, it doesn't matter:/ we translate into the language of a country with no shape/ where our old outlines are every day erased/ shrunk, pierced, ceaselessly deformed/ how may we translate them dilute ourselves survive?» (Torner in Ballart, 2013: 44-45). This example demonstrates how these Catalan poets are 
actually taking advantage of the implications and consequences of translation, as the connections with the Eastern and central European contexts mentioned in the poem «Destraduir Europa» // «Untranslating Europe» become obvious, drawing powerful parallels with the complex and charged linguistic reality the poetic voices live in:

translation, like all (re)writings is never innocent. There is always a context in which the translation takes place, always a history from which a text emerges and into which a text is transposed (Bassnett \& Lefevere, 1990: 10).

\section{CONCLUSIONS}

What comes to light in all the poetry analysed so far in the article is a translation of culture or cultures that works in different directions and with different intentions: the poets collected in Xarnegos-Charnegos (Antología) engage in bilingual poetry aiming to gain access to Catalan tradition, demonstrating their right to become part of Catalan culture, its traditions and its identity regardless of the language they use. Margarit's bilingual poetry allows him to cross borders and successfully position himself in two different literary systems, but it also enables Catalan poetry to visibly cross linguistic and cultural frontiers, becoming a physical presence within the poetic field in Spanish and catering to both Catalan and Spanish readers. Both Xarnegos-Charnegos (Antología) and Joan Margarit's work seem to imply certain degree of pedagogical intent -however laudable it might be-, as if the authors were in a way attempting to educate readers -Catalan or Spanish-in what Catalan identity is, its permeability and hybridity, and also how it can travel through translation. Finally, the poetry of authors translated into English - particularly the anthologies and publications that include the work of many authors, as it gives a sense of plurality, or of something much bigger and global than a sole or specific case- aims to bring Catalan poetry and literary tradition to the world, proving its worth and significance. One of the main advantages of bilingual or even plurilingual publications is obviously the increased number of readers that will be able to engage with the text, but one must not ignore that a translation of a language and a culture may also respond to other multifaceted aims such as maximizing the visibility of a minority language, negotiating cultural distinctiveness, conveying an identity or establishing a dialogue between linguistic communities in a frontier or analogous context. What this means for Catalan poetry at the crossroads, particularly in view of the Independence movement and the recent historical events that push for Catalonia self-government, is an 
enhancement of cultural dialogues that can make Catalan literature and culture even stronger and make «madame» more alive than ever.

\section{WORKS CITED}

Ballart, P. (ed.) (2013): Six Catalan Poets, Todmorden, Arc Publications. BAssnett, S. (2014): Translation, London, Routledge.

Bassnett, S.; A. Lefevere (eds.) (1990): Book Translation, History and Culture, London, Cassell.

Büchlert, A. (2013): «Series Editor's Preface'» in BAllart, P. (ed.) (2013): Six Catalan Poets, Todmorden, Arc Publications, 9.

CANdel, F. (1964): Els altres catalans, Barcelona, Edicions 62.

Cullell, D. (2011): «Rewriting Xarneguisme/ Rewriting Cultures: Xarnego Poetry and Catalan Identity», Journal of Catalan Studies, 14: 24-46.

- (2014): «Crossing Borders: Identity and Culture in Translation in Joan Margarit's Bilingual Poetry», 452 ${ }^{\circ}$ F., 11: 93-109.

Farràs, A.; P. Cullell (2009): El ascensor: charnegos al poder, Barcelona, Angle Editorial.

Ferrater, G. (1953): «Madame se meurt...», Ínsula, 95: 12.

Gentes, E. (2013): «Potentials and Pitfalls of Publishing Self-Translations as Bilingual Editions», Orbis Litteraturam, 68(3): 266-281.

Grutman, R. (2009): «Self-Translation» in Baker, M., G. SAldanha (eds.) (2009): Routledge Encyclopedia of Translation Studies, London, Routledge.

Guibernau, M. (2004): Catalan Nationalism: Francoism, Transition and Democracy, London, Routledge.

KING, S. (2002): «¿Un acento propio? Cultural Difference in Castilian-Language Literature from Catalonia», Letras Pensinsulares, 15(2): 287-301.

- (2005): Escribir la catalanidad: lengua e identidades culturales en la narrativa contemporánea de Cataluña, Woolbridge, Tamesis.

- (2006): «Catalan Literature(s) in Postcolonial Context», Romance Studies, 24(3): 253-264.

Margarit, J. (1999): Estació de França, Madrid, Hiperión.

- (2007): Barcelona amor final, Barcelona, Proa.

- (2009): Misteriosamente feliz, Madrid, Visor.

- (2011): Tots els poemes (1975-2010), Barcelona, Proa.

- (2012): Se pierde la señal, Madrid, Visor.

- (2015): Amar es dónde, Madrid, Visor. 
Palacios, M. (ed.) (2012): Forked Tongues: Basque, Galician and Catalan Women's Poetry in Translations by Irish Writers, Bristol, Shearsman Books.

Pelegrí, I.; A. Crowe (eds.) (2007): Light off Water: XXV Catalan Poems, 1978-2002, Edinburgh, Scottish Poetry Library.

RESINA, J. R. (1999 a): «La identitat al mercat: l'escriptor català i la ideologia del xarneguisme (I)», Diàlegs: Revista d'Estudis Polítics $i$ Socials, 2(4): 23-48.

- (1999 b): «La identitat al mercat: l'escriptor català i la ideologia del xarneguisme (II)», Revista d'Estudis Politics $i$ Socials, 2(5): 45-71.

Rivas, M. (2009): La desaparición de la nieve, Madrid, Alfaguara.

Rosenthal, D. H. (ed.) (1979): Modern Catalan Poetry: An Anthology, St Paul, Minnesota, New Rivers.

Torras, M. (ed.) (2009): El poder del cuerpo: antología de poesía femenina contemporánea, Madrid, Castalia.

Trujillo, N. (ed.) (2010): Xarnegos-Charnegos (Antología), Madrid, Sial.

Vilarós, T. (2003): «The passing of the Xarnego-immigrant: Post-Nationalism and Ideologies of Assimilation in Catalonia», Arizona Journal of Hispanic Studies, 7: 229-246. 